\title{
Dual Banking System Stability Index in the Shadow of COVID-19 Pandemic ${ }^{1}$
}

\author{
Patria Yunita ${ }^{2}$
}

Corresponding email: patria.yunita@gmail.com

\author{
Article History: \\ Received: May 30 ${ }^{\text {th }}, 2021$ \\ Revised: September $21^{\text {st }}, 2021$ \\ November $25^{\text {th }}, 2021$ \\ January $3^{\text {rd }}, 2022$ \\ January $12^{\text {th }}, 2022$ \\ Accepted: January $18^{\text {th }}, 2022$
}

\begin{abstract}
The financial system is categorized as stable if there is no excessive volatility from financial pressures or crises. The IMF indicates that the crisis is not only related to one element but more than two or three elements of the crisis. The banking system's stability is measured by the banking stability index, gauging the effectiveness of monetary policy and financial risk. This study aims to measure the stability of the Indonesian banking system in the dual banking system model. The indicator to measure banking stability used the Z-score statistic based on fluctuations of Return on Assets for each type of bank. The Markov Switching Vector Autoregressive (MSVAR) model method was used to analyze the volatility of banking stability. Independent variables used included credit risk (NPL), Loan to Deposit Ratio, Liquidity Risk, Net Interest Margin, Capital Adequacy Ratio, Money Market Rate, Inflation, Gross Domestic Product, Federal Reserve rate, and Exchange Rate. The results of the regime switch analysis concluded that Indonesia's banking stability experienced a structural break due to the effects of the pandemic in April 2020. Based on the average Z-score value, the Islamic banking stability index was higher than conventional banking. In other words, Islamic banking was more stable than the conventional banking system. The Islamic banking stability index (iZscore) was significantly influenced by the level of Net Operating Margin, Financing to deposit ratio, Potential Loss Profit Sharing, Islamic Money Market Rate, and Exchange Rate. However, non-performing financing did not affect Islamic banking stability since the profit-sharing system implemented by Islamic banking stability was more influenced by the ratio of potential loss and profit-sharing system.
\end{abstract}

Keywords: Dual banking system, Z-score, Markov switching

JEL Classification: G01; G21; G32; G33

Type of Paper: Research Paper

@IJIEF 2022 published by Universitas Muhammadiyah Yogyakarta, Indonesia

DOI:

Web:

https://doi.org/10.18196/ijief.v5i1.11837 https://journal.umy.ac.id/index.php/ijief/article/view/11837

Citation:

Yunita, P. (2022). Dual Banking System Stability Index in the Shadow of COVID-19 Pandemic. International Journal of Islamic Economics and Finance (IJIEF), 5(1). 151-176. DOI: https://doi.org/10.18196/ijief.v5i1.11837.

\footnotetext{
1 This paper has been presented on the 7th Indonesia Finance Association (IFA) International Conference

"Finance, Capital Market, and Corporate Governance in the Digital Transformation Era" on October 6 \& 7, 2021. IDX, KSEI, IFA.

2 Sekolah Tinggi Ekonomi dan Perbankan Islam Mr. Sjafruddin Prawiranegara
} 


\section{Introduction}

\subsection{Background}

Successful economic development is measured by the effectiveness and performance of financial institutions, especially the banking industry. The financial systems have gone through several significant changes throughout Southeast Asia due to the banking crisis. Banking performance can affect the efficiency and stability of the banking industry and the overall effectiveness of the financial system because the banking system is still a priority for intermediary institutions in Southeast Asian countries. Banks are also the main institutions that mobilize domestic deposits as a major payment system player and external corporate capital source (Kočišová, 2011).

Unstable economic conditions are indicated by the high volatility of macroeconomic indicators and impact the banking sector. The researchers used various statistical indicators to describe the characteristics of financial system resilience, evaluating the dimensions of financial stability related to risk as to the main indicators of micro and macroprudential. On the other hand, one of the consequences of the global financial crisis is the growth of credit risk and increased non-performing loans (Kočišová, 2011). The most critical financial crisis in Asian economies, including Indonesia, was the financial crisis that occurred in mid-1997 and affected currency exchange rates, stock markets, and asset prices (Zahra, Ascarya \& Huda, 2018). Several indicators that affect the banking system's stability are credit risk, liquidity risk, capital adequacy, exchange rate risk, interest rate risk, and other risks inherent to the banking system. Mishkin (2011) mentions that the banking sector will be bankrupt if total assets are lower than the total loan.

Moreover, the IMF indicates that the crisis is not only related to one element but more than two or three elements of the crisis. In 1997, there were 148 banking crises and 218 cases of exchange rate crises (Laevan and Valencia, 2012). Banking crises usually begin with skyrocketing asset prices, high capital income, and credit booms (Reinhart and Rogoff, 2013). Four factors influence financial system stability: a) a stable economic environment, b) well-managed financial institutions, c) effective oversight of financial institutions, and d) secure and reliable payment systems. If an interruption occurs in one subsector, it will affect other sub-sectors (Gadanecsz \& Kaushik, 2008).

The prolonged pandemic since November 2019 has had a very significant impact on the global economy. According to (Elnahass et al., 2021), the world began to realize the serious impact of the pandemic since the end of February 2020, following the development in China, Europe, and the United States. IMF (International Monetary Fund [IMF], 2020) pointed out a 3\% contraction of 
the global economy starting in April 2020, where financial institutions, especially the banking sector, have suffered an immediate exogenous shock that required them to be prepared for difficulties of future challenges. Meanwhile, besides these challenges, there are high expectations that banks should be an active part of the wide economic solution and support government efforts against recessive factors through pandemic risks since banks remain the main source of liquidity for economies (Barattieri, Eden \& Stevanovic, 2020). Many researchers have analyzed banking stability using the financial stability indicator or Z-score. International Monetary Fund using Zscore to measure banking stability index. Meanwhile, Schaeck \& Cihak (2014) used inzscore generated from expected return on average assets.

Besides the conventional banking system, the Islamic banking system operates globally to avoid the dangers of usury. Several countries have begun to implement an Islamic banking model. The Islamic banking model is a banking component with a unique and different management pattern. According to data published by the World Bank, the main issue related to banking studies is that the dual banking system has been adopted by more than 50 countries and has achieved significant growth, so it impacts the level of stability. The stability of the banking system is measured by the banking stability index. The banking stability index can describe the effectiveness of monetary policy and includes the financial risk of monetary policy decisions. The financial system is categorized as stable if there is no excessive volatility from financial pressures or crises.

Most previous researchers used Z-score to analyze the banking stability index. Some of them used neural networks and camels indicators. Studies successfully applied the banking stability index measurement but did not calculate the switching process from stable to unstable. Therefore, this paper analyzes the banking stability measurement of the dual banking system to have an earlier warning of Indonesia's banking crises through pandemic using Z-score, calculated based on accounting ratio of the asset performance rather than market data. The researchers analyzed the switching process from stable to unstable conditions and compared banking stability between Islamic and conventional banking systems in pandemic conditions. Then, the purpose of this paper is to present a quantitative examination of what occurred during the pandemic in different banking business models (i.e., Islamic and conventional banks).

Before, the IMF (2020) projected that the substantial economic recovery from pandemic effects is a subject of the current extraordinary policy and the adequate renegotiation of bank loans to preserve the financial system's stability actively. The non-performing loans measure loan risks, known as the 
lagging indicators of banking soundness (Schaeck \& Cihak, 2014). In Indonesia, from January 2015 to February 2021, the Loan to Deposit Ratio of conventional and Islamic banking showed a very sharp decline. Likewise, conventional banks' Net Interest Margin ratio showed a sharp decline. It affected the distribution of corporate credit in the Indonesian economy. Thus, the study of the impact of the pandemic on global banking stability is an important part of assessing the potential for signs of economic recovery. In February 2020, the global world began to realize the serious impact of the global economy due to the pandemic. Global capital markets were heavily affected during the first weekend of March 2020. The outbreak has also forced international institutions and large banks to cut their growth (Donthu \& Gustafson, 2020; Sharma, Leung, Kongshott, Davcik \& Cardinali, 2020). In Indonesia, following the regulation from IMF, the banking stability regulator issued a policy of tightening liquidity.

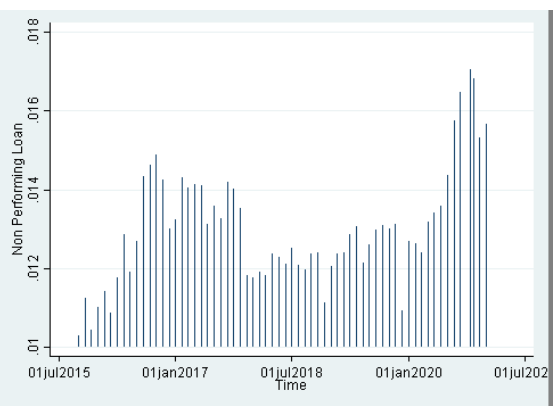

(a) Conventional

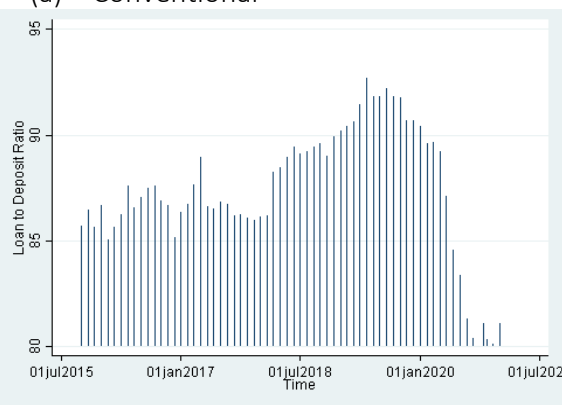

(a) Conventional

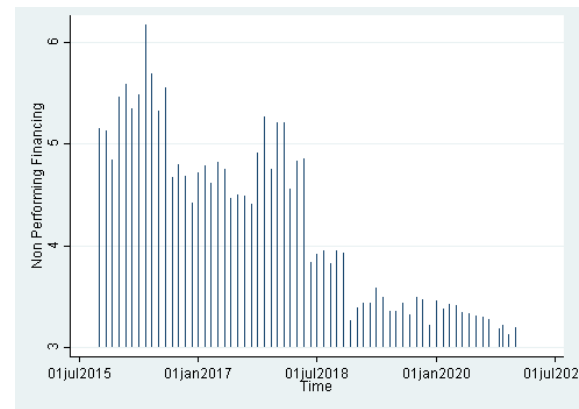

(b) Islamic

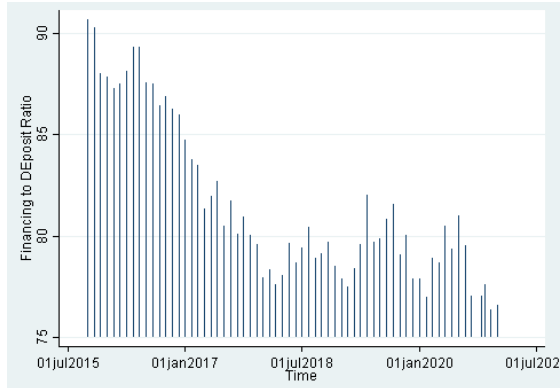

(b) Islamic

Figure 1. Level of Bank Non-Performing Loan and Loan to Deposit Ratio, Indonesia Banking Industry, January 2015 to February 2021

Source: Statistic of Indonesia Banking Industry, The Financial Services Authorities. 2021.

As a consequence of this regulation, the number of conventional and Islamic banking lending has decreased drastically. Figure 1 illustrates the fluctuations of the Loan to Deposit Ratio and Non-Performing Loans of Indonesia conventional and Islamic banking from October 2015 to January 2021. Although the NPL ratio impacts economic growth, the risk of bad loans can be controlled through the pandemic condition. Elnahass et al. (2021) mentioned that the COVID-19 outbreak had had a very detrimental impact on financial 
performance (i.e., accounting-based and market-based performance measures) and in various financial stability indicators (default risks, liquidity risks, and assets risks). Meanwhile, Indonesia banking bad debts are quite controlled in a pandemic situation.

\subsection{Research Objectives}

This study aims to measure the stability of Indonesia's dual banking system through pandemic diseases using a Z-score index based on accounting ratio rather than market data to present a quantitative examination of what occurred during the pandemic in different banking business models (i.e., Islamic and conventional banks). The pandemic conditions have been impacted the Southeast Asia financial sector, including Indonesia, and have been impacted the Islamic and conventional banking industry differently.

The remaining organization of the paper discusses literature review related to theory and past studies related to the topic in chapter two, followed by methodology in chapter three, discussing methodology, including the data, proposed stability model and regression method used. Chapter four discusses results and analysis, followed by chapter five, discussing the study's conclusion and recommendations for various stakeholders.

\section{Literature Review}

\subsection{Banking System Stability}

Financial system stability is indicated by the fluctuation of the money market, stock market, and banking sector. Gorton \& Winton (2003) argues that banks are liquidity providers. Banks have an important role that can affect the sensitivity of financial markets and economic stability. Evaluation of bank stability and soundness is a complex task and involves a large number of multidimensional criteria (Kosicova, 2011). The financial system can be said to be stable if there is no excessive volatility and crisis. Financial stability is a condition in which banking institutions, capital markets, and money markets, including financial infrastructure, can withstand shocks and break down financial imbalances, thereby reducing the possibility of disruption in the intermediary financial process (Gadanecsz \& Kaushik, 2008). The International Monetary Fund (2020) has developed financial stability indicators to measure the level of banking stability based on the international balance system (Kocisova, 2011).

The measurement of banking stability also uses Z-score analysis. The IMF uses the Z-score to evaluate the level of banking stability. Z-score is a popular analysis method to measure banking stability performance among many 
researchers. The Z-score calculation is based on historical accounting data on banking financial statements (IMF, 2015).

$$
Z \text { score }=\frac{(k+\mu)}{\sigma R O A}
$$

The greater the result of the Z-score, the more stable the conditions (Martin \& Hesse, 2010) A higher Z-score indicates lower insolvency risk (Albuquerque \& Rahji, 2019).

There are modifications of the Z-score from previous research. Rajhi\&Hassan (2013) used a Z-score, calculated by the expected return of average assets. Meanwhile, Abedifar et al. (2012) used Z-score for insolvency risk by the formula:

$$
Z \text { score }=\frac{E(R O A)+C A R}{\sigma R O A}
$$

\subsection{Previous Studies}

Several studies of financial system stability have been carried out by Alqahtani \& Mayes (2018), Nurfalah et al. (2018), Zahra, Ascarya \& Huda (2018), Nurfalah \& Rusydiana (2020), and many other researchers. Elnahass et al. (2021) assessed 1090 banks from 116 countries throughout 2019 - 2020, and the results provide strong empirical evidence that in the global banking sector, the COVID-19 outbreak has had a very detrimental impact on financial performance (i.e., accounting-based and market-based performance measures) and in various financial stability indicators (default risks, liquidity risks and assets risks). The results are consistently observed in the US, China, and others, in different countries' bank levels and income levels.

Ryu \& Yu (2020) identified the effect of subordinated loans on bank performance using several variables. Their research concluded that the loan's size would affect the bank's performance; the high level of the loan would result in a low level of bank solvency. Besides, Nurfalah \& Rusydiana (2020) researched Indonesia, Malaysia, and Pakistan's banking instability. Their research denoted that banking instability in Indonesia is largely influenced by fluctuations of the inflation rate, while banking instability in Malaysia and Pakistan is influenced by the financing to deposit ratio and fluctuations in world oil prices.

Albuquerque \& Rajhi (2019) evaluated the effects of natural disasters in developing economic countries, using inzscore to represent financial stability. The results concluded that shocks from natural disasters affected nonperforming loans temporarily, while shocks from state fragility created 
detrimental economic. Meanwhile, Lee \& Lee (2019) predicted the effect of world oil prices on banking performance in China. The results of their research concluded that an increase in oil prices resulted in lower banking liquidity, profitability, capital and management efficiency.

Ozili (2018) research on the determinants of Islamic banking in Africa concluded that indicators affecting banking stability in Africa included efficiency, political stability, corruption control, regulatory control, bank size, and unemployment rate. In addition, Sanchez et al. (2016) analyzed credit risk and corporate failure of bankruptcy prediction using the hybrid associative memory method. The method is an alternative technique to predict financial systems through a neural network. Also, Kocisova (2011) measured the banking stability index across European countries. The index is categorized into four items: capital adequacy, asset quality, earnings and profitability, and liquidity. The aggregate banking stability is calculated as the sum of weighted values of four categories.

Kabir et al. (2015) conducted a study to consider the levels of credit risk in Islamic and conventional banks. Their study evaluated 156 conventional and 37 Islamic banks across 13 countries between 2000 - 2012, using marketbased credit risk measure, Merton's distance to default (DD) Model. The study concluded that Islamic banks had significantly lower credit risks.

Rajhi \& Hassairi (2013) investigated the stability of Islamic banks and conventional banks in 16 countries of the Middle East, North Africa, and Southeast Asian countries over 2000-2008 using Z-score. Their model was generated using panel regression of Z-score, calculated by the expected return of average assets. The study found that Islamic banks indicated higher stability than conventional banks.

Abedifar et al. (2012) researched Islamic banking risk using 553 banks from 24 countries in 1999 - 2009. Abedifar et al. (2012) used Z-score for insolvency risk analysis; Z-score formula in their research is as follows: zscore $=$ $\frac{E(R O A)+C A R}{\sigma R O A}$., where $\mathrm{E}(\mathrm{ROA})$ is the expected return on assets, and $\sigma R O A$ is the standar deviation of ROA. Their results concluded that Islamic banks had lower credit risk than conventional banks, and the loan quality of Islamic banks was less responsive to the domestic interest rate.

Ghosh (2011) measured the stability of 28 banks in the 1997-2007 period using regression analysis. The results of his study indicated that the addition of branches opened up risk diversity and positively affected banking stability. Meanwhile, Cihak et al. (2008) measured banking stability using data from 2003-2004 using regression analysis of the banking Z-score value. 
(Martin \& Hesse, 2010) identified a significant impact of Islamic banks' market share on financial risk system using the ratio of total loans to total assets, but this research did not analyze interest rates risks. Their model used panel regression of Z-score from 19 countries to calculate banking stability. Z-score was generated from return on assets as a proxy of return volatility of banks.

It can be seen that most previous researchers used Z-score to analyze the banking stability index. Some of them used neural networks and camels indicators. The studies successfully applied the banking stability index measurement but did not calculate the switching process from stable to unstable. For this reason, this research employed a Z-score, calculated by the fluctuation of ROA and Markovswitch VAR, to analyze the regime switch from stable to unstable conditions. This research follows the study conducted by Nurfalah et al. (2018), Zahra, Ascarya \& Huda (2018), and Nurfalah \& Rusydiana (2021). Nurfalah et al. (2018); Nurfalah \& Rusydiana (2021) conducted banking stability and regime-switching model for the Islamic banking system in Indonesia, Malaysia, and Pakistan. Their study mentioned that Indonesia's banking stability index was affected by inflation, while Malaysia and Pakistan were affected by the financing to deposit ratio and the fluctuation of global oil.

Following the previous research regarding the banking stability index, we conducted our analysis by dividing our model into two models. The first model is the conventional banking stability index, and the second model is the Islamic banking stability index. The banking stability index denoted by Z-score was calculated based on the accounting ratio of the asset performance rather than the market data. Then, we analyzed the switching process from stable to unstable conditions and compared banking stability between Islamic and conventional banking systems. Next, we divided our variables into independent and control variables. The independent variable is internal banking performances, while control variables are generated by the external macroeconomic indicators. In this regard, Elnahass et al. (2021) mentioned that the COVID-19 outbreak had had a very detrimental impact on financial performance (i.e., accounting-based and market-based performance measures) and in various financial stability indicators (default risks, liquidity risks and assets risks), while Indonesia banking bad debts are quite controlled in the pandemic situation due to government regulations. 


\section{Methodology}

\subsection{Data}

Table 1. Research Variables for Conventional Banking

\begin{tabular}{cccc}
\hline Variable & Proxy & Notation & Data sources \\
\hline $\begin{array}{c}\text { Dependent Variable } \\
\text { Z-score }\end{array}$ & Z score $=\frac{(k+\mu)}{\sigma R O A}$ & Z score & $\begin{array}{c}\text { Stantistics } \\
\text { Financial Services } \\
\text { Authority }\end{array}$ \\
\hline $\begin{array}{c}\text { Independent Variables } \\
\text { Capital Adequacy Ratio }\end{array}$ & CAR & CAR & Indonesian Economic \\
Net Interest Margin & NIM & NIM & Bnd Financial Statistics, \\
Loan to Deposit Ratio & LDR & LDR & Indonesian Financial \\
Liquid Assets & LA & LA & Stability Review, Bank \\
Money Market Rate & Indonesia \\
\hline Control Variables & & MM & Indonesian Economic \\
inflation & INF & INF & and Financial Statistics, \\
Gross Domestic Product & GDP & GDP & Bank Indonesia \\
Federal Reserve & FED & FED & Indonesian Financial \\
Exchange rate & EXC & EXC & Stability Review, BI \\
\hline
\end{tabular}

Table 2. Research Variables For Islamic Banking

\begin{tabular}{|c|c|c|c|}
\hline Variable & Proxy & Notation & Data sources \\
\hline $\begin{array}{c}\text { Dependent Variable } \\
\text { Z-score }\end{array}$ & $Z$ score $=\frac{(k+\mu)}{\sigma R O A}$ & Z score & $\begin{array}{c}\text { Bank Indonesia } \\
\text { Statistics } \\
\text { Financial Services } \\
\text { Authority } \\
\end{array}$ \\
\hline $\begin{array}{l}\text { Independent Variables } \\
\text { Non-Performing Financing } \\
\text { Net Operational Margin } \\
\text { Financing to Deposit Ratio } \\
\text { Profit \&Loss Sharing Financing } \\
\text { Islamic Money Market Rate }\end{array}$ & $\begin{array}{l}\text { NPF } \\
\text { NOM } \\
\text { FDR } \\
\text { PLS } \\
\text { IMM }\end{array}$ & $\begin{array}{l}\text { NPF } \\
\text { NOM } \\
\text { FDR } \\
\text { PLS } \\
\text { IMM }\end{array}$ & $\begin{array}{c}\text { Indonesian Economic } \\
\text { and Financial } \\
\text { Statistics, Bank } \\
\text { Indonesia } \\
\text { Indonesian Financial } \\
\text { Stability Review, Bank } \\
\text { Indonesia }\end{array}$ \\
\hline $\begin{array}{c}\text { Control Variables } \\
\text { inflation } \\
\text { Gross Domestic Product } \\
\text { Federal Reserve } \\
\text { Exchange rate }\end{array}$ & $\begin{array}{l}\text { INF } \\
\text { GDP } \\
\text { FED } \\
\text { EXC }\end{array}$ & $\begin{array}{l}\text { INF } \\
\text { GDP } \\
\text { FED } \\
\text { EXC }\end{array}$ & $\begin{array}{c}\text { Indonesian Economic } \\
\text { and Financial } \\
\text { Statistics, Bank } \\
\text { Indonesia } \\
\text { Indonesian Financial } \\
\text { Stability Review, BI } \\
\end{array}$ \\
\hline
\end{tabular}

The data used in this study were Indonesian Banking Statistics Data and Indonesian Economic and Financial Statistics reported monthly by Bank Indonesia and the Financial Services Authority in the research period October 2015 to January 2021. Ten variables were used in this study, including Z-score (indicators of banking stability) as the dependent variable is described in Table 1 for conventional banking and Table 2 for Islamic banking. The independent variables were capital Adequacy Ratio, Non-Performing Loan, Net Interest Margin, Loan to Deposit ratio, Liquid Assets, and Money Market Rate. 
Meanwhile, the control variables were Inflation, Gross Domestic Product, Federal Reserve, and Exchange Rate.

\subsection{Model Development}

We used two Z-score equation models to analyze the stability measurement of the dual banking system in Indonesia. The Z-score equation is a stability measurement used by the International Monetary Fund to calculate banking stability (IMF, 2015). Many researchers have also used Z-score to calculate banking stability measurement (Cihak \& Hesse, 2010; Rajhi \& Hassairi,2013). In this paper, we used two general equation models. Model 1 is the equation of conventional banking stability, and model 2 is the Islamic banking stability. Our models refer to studies conducted by Nurfalah et al. (2018), Zahra, Ascarya \& Huda (2018), and Nurfalah \& Rusydiana (2021).

\subsubsection{General Equation of Research Model}

Model 1 (Conventional Banking Stability)

$$
\begin{aligned}
\mathrm{Z}-\text { score } \quad \mathrm{K}_{\mathrm{t}}= & \beta_{0}+\beta_{1} \mathrm{CAR}_{\mathrm{t}-\mathrm{j}}+\beta_{2} \mathrm{NIM}_{\mathrm{t}-1}+\beta_{3} \mathrm{LDR}_{\mathrm{t}-\mathrm{m}}+\beta_{4} \mathrm{LA}_{\mathrm{t}-\mathrm{n}}+\beta_{5} \mathrm{MM}_{\mathrm{t}-0} \\
& +\beta_{6} \mathrm{EXC}_{\mathrm{t}-\mathrm{p}}+\beta_{7} \mathrm{INF}_{\mathrm{t}-\mathrm{p}}+\beta_{8} \mathrm{GDP}_{\mathrm{t}-\mathrm{p}}+\beta_{9} \mathrm{FED}_{\mathrm{t}-\mathrm{p}}+\varepsilon t
\end{aligned}
$$

$\begin{array}{ll}\text { Z-score } & \text { : Stability Index } \\ \text { CAR } & : \text { Capital Adequacy of Conventional Banks } \\ \text { NPL } & : \text { Credit Risk } \\ \text { NIM } & : \text { Net Interest Margin } \\ \text { LDR } & : \text { Loan to Deposit Ratio } \\ \text { LA } & : \text { Liquidity Assets } \\ \text { MM } & : \text { Interbank Money Market Rate } \\ \text { INF } & : \text { Inflation Rate } \\ \text { GDP } & : \text { Gross Domestic Product } \\ \text { FED } & : \text { Federal Reserve } \\ \text { EXC } & : \text { Exchange rate }\end{array}$

Model 2 (Islamic Banking Stability)

$$
\begin{aligned}
& \text { izscore }_{\mathrm{K}_{\mathrm{t}}}=\beta_{0}+\beta_{1} \mathrm{NOM}_{\mathrm{t}-\mathrm{j}}+\beta_{2} \mathrm{NPF}_{\mathrm{t}-\mathrm{k}}+\beta_{3} \mathrm{LIQ}_{\mathrm{t}-1}+\beta_{4} \mathrm{FDR}_{\mathrm{t}-\mathrm{m}}+\beta_{5} \mathrm{PLS}_{\mathrm{t}-\mathrm{n}} \\
& +\beta_{6} \mathrm{IMM}_{\mathrm{t}-0}+\beta_{7} \mathrm{INF}_{\mathrm{t}-\mathrm{p}}+\beta_{8} \mathrm{GDP}_{\mathrm{t}-\mathrm{p}}+\beta_{9} \mathrm{FED}_{\mathrm{t}-\mathrm{p}}+\beta_{10} \mathrm{EXC}_{\mathrm{t}-\mathrm{p}}+\varepsilon t
\end{aligned}
$$

$\begin{array}{ll}\text { iZscore } & \text { : Islamic Banking Stability Index } \\ \text { NOM } & \text { : Net operating margin } \\ \text { NPF } & : \text { Non-Performing Loan } \\ \text { LIQ } & : \text { Liquidity rate } \\ \text { FDR } & : \text { Financing to Deposit ratio } \\ \text { Pls } & : \text { Potential Loss Profit Sharing } \\ \text { IMM } & : \text { Islamic interbank Money Market Rate } \\ \text { INF } & : \text { Inflation rate }\end{array}$




$\begin{array}{ll}\text { GDP } & : \text { Gross Domestic Product } \\ \text { FED } & : \text { Federal Reserve } \\ \text { EXC } & : \text { Exchange rate }\end{array}$

\subsection{Method}

\subsubsection{The Markov Switching Model}

The IMF uses the Z-score as an indicator to measure banking stability. Referring to the IMF's calculation of banking stability, this study used a banking stability index with Z-score. After calculating the Z-score value, the MS-VAR (Markov Switching - Vector Autoregressive Models) switch method was employed. The Markov Switching Model was developed by Hamilton in 1989 to analyze the dynamics of the business cycle econometrically. This method accommodates multivariate variables and linear time series data with constant parameters (Krolzig, 1997). The Markov switching model combines the linear autoregressive model with the Markov chain model, known as the autoregressive Markov switching model. It is because the dynamics of the business cycle are influenced by several macroeconomic factors. Markov switching model is also used to analyze time-series data in the economic and financial fields that experience changes in conditions due to a structural break.

The Markov switching model is a dynamic regression model that shows different dynamics across the observed states using parameters that accommodate structural breaks or other state phenomena. This model is a transition between an unobserved state and a Markov chain. There are two Markov switching models: the Markov switching dynamic regression (MSDR) model, which allows quick adjustments after the change process, and the Markov switching autoregression (MVAR) model, which allows gradual adjustments. Markov switching vector autoregressive (MSVAR) model is a non-linear model that combines the autoregressive linear vector model with the Markov chain model (Krolzig, 1997).

The assumption that must be met for Markov switching modeling is the assumption of stationarity. If a time series is stationary, the data variance is not affected by changes in time, so it is in statistical equilibrium (Gujarati, 2003). In this study, to measure stationarity in time series data, the Augmented Dickey-Fuller method was used. The augmented Dickey-Fuller test is a unit root test to test data stationery, with the following hypothesis:

Ho: Data contains unit root or non-stationary data.

H1: Data does not contain unit-roots, or data is stationary.

$$
t=\frac{\dot{\varphi}-1}{\sigma(\dot{\varphi})}
$$




\subsubsection{Optimal Lag Determination}

By using the Swatch Criterion, the optimal lag determination was carried out using the following formula:

$$
S C=-2 \frac{\lambda}{T}+\frac{\ln (T)}{T} K
$$

Where $\mathrm{T}$ is the number of data, $\mathrm{k}$ is the number of variables, and $\lambda$ is the loglikelihood function.

The Markov switching vector autoregression model was used in this study because of the multivariate model. There are two Markov switching vector autoregressive components: VAR and Markov chain. Krolzig (2000) stated that the general form of the Markov switching vector autoregressive model of order $\mathrm{p}$ or $\mathrm{MS}(\mathrm{M})-\mathrm{VAR}(\mathrm{p})$ is as follows:

$$
y_{t}=c\left(S_{t}\right)+A_{1}\left(S_{t}\right) y_{t-1}+\cdots+A_{p}\left(S_{t}\right) y_{t-p}+\varepsilon_{t}
$$

The MSVAR model assumes that the condition variable is an unobservable random variable, called the hidden Markov model, probability of the transition from the initial state to the next state. The main idea of this model is that the time series parameter of the $\mathrm{K}(\mathrm{yt})$ dimension vector depends on the unobserved variable, with the following formula: $S_{t}$

$$
p\left(y_{t} \mid Y_{t-1}, X_{t} S_{t}\right)=\left\{\begin{array}{cc}
f\left(y_{t} \mid Y_{t-1},\right. & \left.X_{t} ; \theta_{t}\right) \\
f\left(y_{t} \mid Y_{t-1},\right. & \left.X_{t} ; \theta_{M}\right)
\end{array}\right\} \begin{gathered}
\text { if } S_{t}=1 \\
\text { if } S_{t}=M
\end{gathered}
$$

With $Y_{t-1}=\left\{y_{t-i}\right\}=\frac{\infty}{i} y_{t} X_{t}$ is the historical value of $y_{t}$, which $X_{t}$ is an exogenous variable, and the vector parameter at the time of regime $m$. The Markov switching regression model can be defined as follows:

$$
y_{t}=\left\{\begin{array}{c}
\mathrm{f}\left(\mathrm{y}_{\mathrm{t}} \mid \mathrm{Y}_{\mathrm{t}-1,} \mathrm{X}_{\mathrm{t}} ; \theta_{\mathrm{t}}\right) \\
\mathrm{f}\left(\mathrm{y}_{\mathrm{t}} \mid \mathrm{Y}_{\mathrm{t}-1,}, X_{\mathrm{t}} ; \theta_{\mathrm{M}}\right)
\end{array}\right\} \begin{gathered}
\text { if } \mathrm{S}_{\mathrm{t}}=1 \\
\text { if } S_{\mathrm{t}}=\mathrm{M}
\end{gathered}
$$

There are several specifications of the MSVAR model in the time series model. The notation commonly used for model specifications is for variable changes to regime changes as follows: $M($ mean $(\mu)$ ); I (intercept); A (autoregression parameter (At), and $H$ (heteroscedasticity) (Untoro et al., 2014). This study used a latent variable following the first derivative of Markov's two-state, i.e., St $=1$ is the crisis state, and St $=0$ is a tranquil state. In the Markov switching model (Hamilton, 1989), the transition from one regime to another is governed by an unobserved Markov chain. In the structural change model (Chow 1960, Bai and Perron 2003), the transition from one regime to another is governed by time. Meanwhile, in the autoregressive threshold model (Tong \& Lim, 1980, Van Dijk et al., 2002), the shift from one regime to another is 
governed by the dependent variable compared to the threshold variable. Parameter estimation used the maximum likelihood estimation (MLE) method. The best model is the one with the smallest AIC. Diagnostic tests were then conducted to test the feasibility of the model. The test consisted of a parameter significance test, residual normality, and residual independence.

\subsubsection{Research Stages}

Our research stages are as follows:

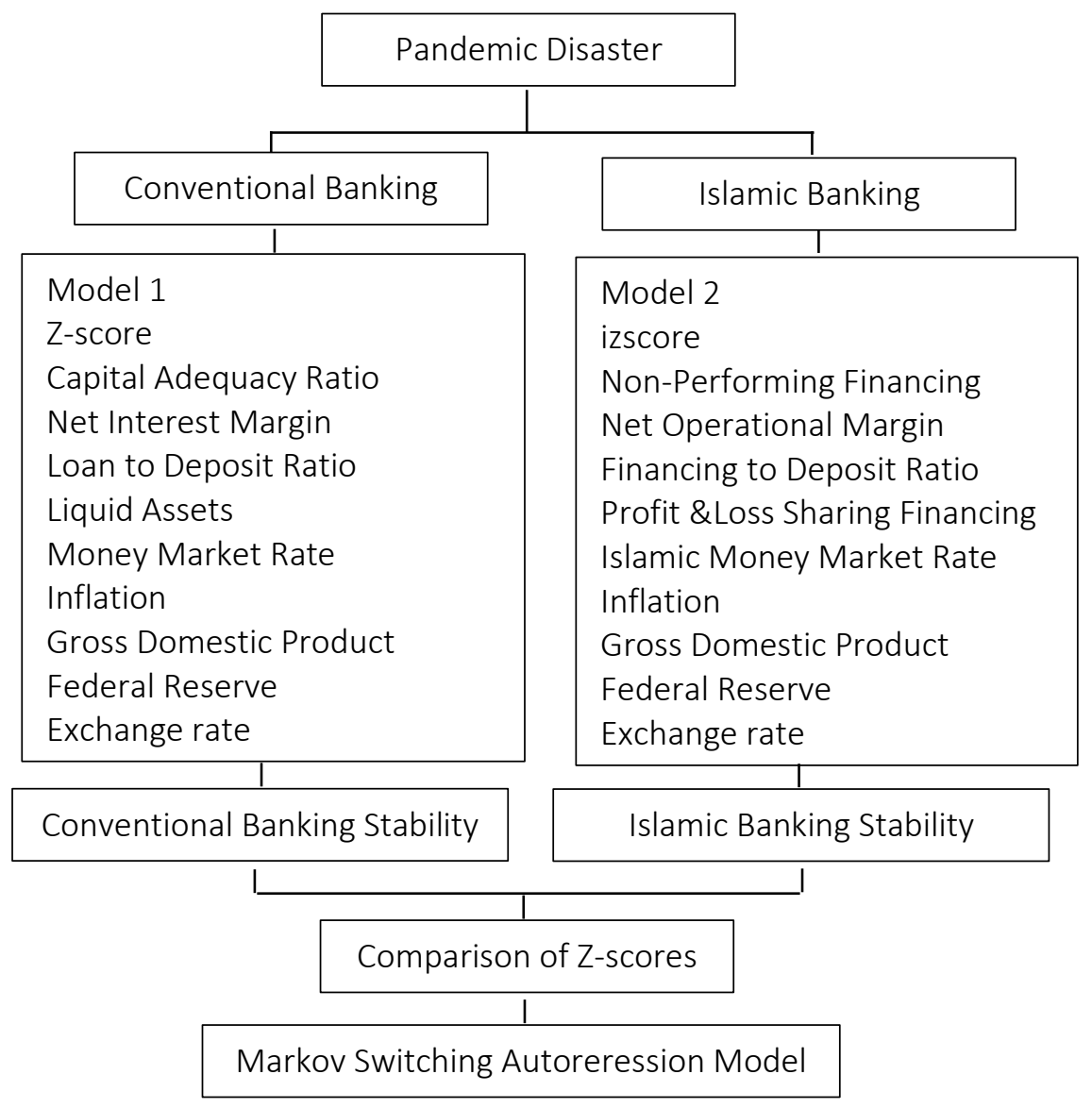

\section{Results and Analysis}

\subsection{Results}

\subsubsection{Descriptive Statistics: Dependent Variable}

This research model uses Z-score analysis as the dependent variable to represent the Indonesian banking stability index. We used Z-score extensively applied in the banking literature to measure the bank stability index. The International Monetary Fund also uses Z-score to measure banking stability. The Z-score measures the standard deviation that the bank's return has to diminish to deplete equity. A higher value of the Z-score means a lower 
probability of insolvency risk and, therefore, better bank stability (Risfandy, Tarazi, \& Trinugorho., 2018). In this study, Z-score was calculated based on Return on Assets performance. Table 3 is a summary of ROA fluctuations in conventional and Islamic banking.

Table 3 shows that the average profitability performance of conventional banks was higher than Islamic banks. However, based on Figure 2, it can be seen that the level of conventional banking profitability during the pandemic decreased, whereas Islamic banks tended to increase.

Table 3. Summary of ROA

\begin{tabular}{lccccccc}
\hline \multicolumn{1}{c}{ Variable } & Obs & Mean & Std. Dev & Min & Max & Skewness & Kurtosis \\
\hline Islamic & 64 & 1.156357 & 0.4241084 & 0.1621272 & 1.875145 & -0.304562 & 2.13875 \\
Conventional & 64 & 2.955323 & 0.3757294 & 1.841875 & 3.534403 & -1.581913 & 4.990583 \\
\hline
\end{tabular}
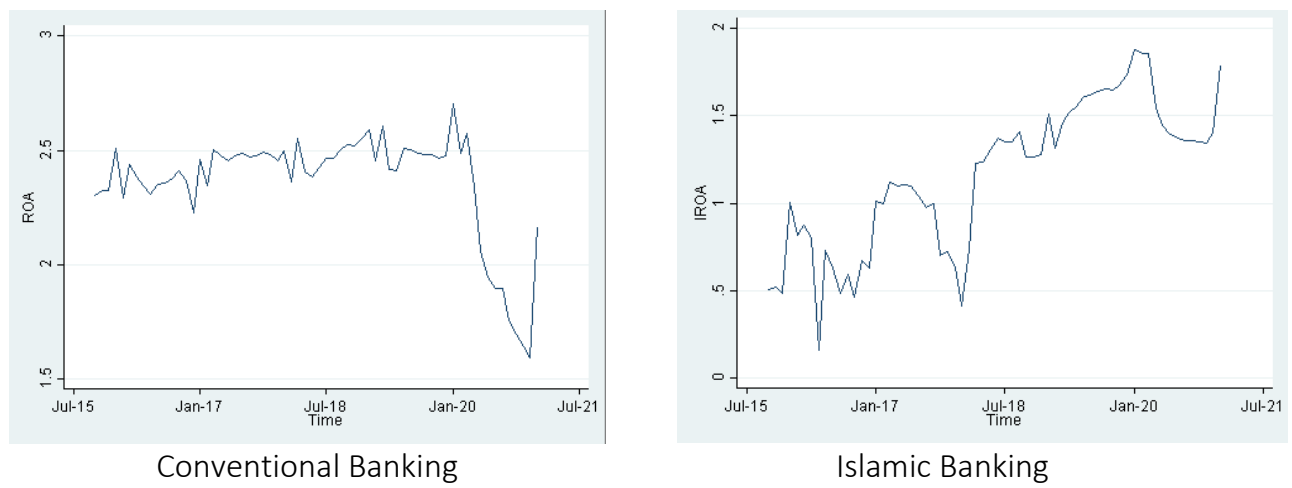

Figure 2. ROA Fluctuations

Table 4. Descriptive Statistics of Islamic and Conventional Stability Index by Z-score

\begin{tabular}{lccccccr}
\hline \multicolumn{1}{c}{ Variable } & Obs & Mean & Std. Dev & Min & Max & Skewness & Kurtosis \\
\hline Islamic & 64 & $5.69 \mathrm{e}-16$ & 1 & -2.344282 & 1.694821 & -0.304562 & 2.13875 \\
Conventional & 64 & $-1.53 \mathrm{e}-15$ & 1 & -2.963429 & 1.541217 & -1.581913 & 4.990583 \\
\hline
\end{tabular}

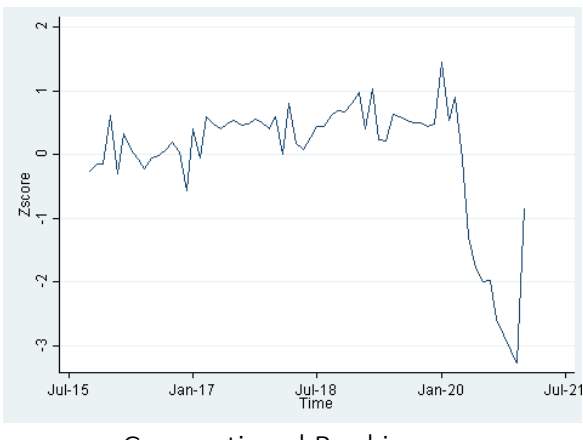

Conventional Banking

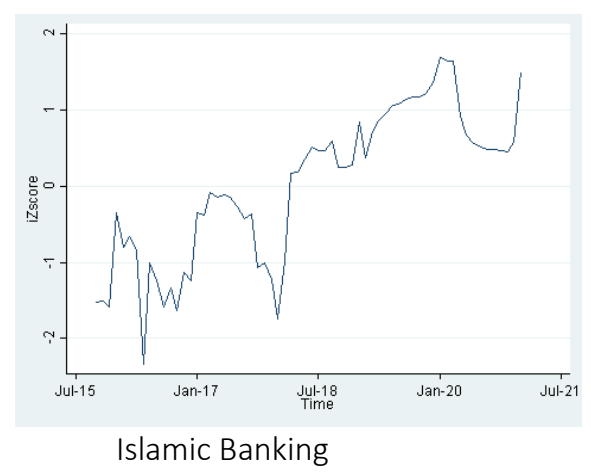

Islamic Banking

Figure 3. Fluctuations of the Indonesian Banking Stability Index (Z-score)

Table 4 describes the analysis of the Islamic banking stability index, represented by the Z-score value. The greater the result of the Z-score is, the 
more stable the conditions (Cihak and Hesse, 2008). In table 4, it can be concluded that the Z-score of conventional banking was negative, while the Zscore of Indonesian Islamic banking was positive. Based on (Cihak and Hesse, 2008), Islamic banking is more stable than conventional banks.

Figure 3 depicts the fluctuation of Indonesia's banking stability index. The Zscore value of Islamic banking decreased, while the Z-score of Islamic banks increased.

\subsubsection{Descriptive Statistics: Independent Variable}

Table 5 describes the descriptive statistics for Islamic banking model. Meanwhile, the descriptive statistics of conventional banking is describes in Table 6.

Table 5. Descriptive Statistics of Islamic Banking Model

\begin{tabular}{lccccc}
\hline \multicolumn{1}{c}{ Variable } & Obs & Mean & Std. Dev & Min & Max \\
\hline NUMBER & 64 & 1.256761 & 0.4489206 & 0.1687105 & 1.928098 \\
iCAR & 64 & 18.42291 & 2.337843 & 14.72363 & 21.80282 \\
NPF & 64 & 4.220886 & 0.8429688 & 3.128563 & 6.168241 \\
FDR & 64 & 81.54512 & 3.986583 & 76.36069 & 90.67393 \\
PL & 64 & 3.224995 & 0.4819118 & 2.369912 & 4.458928 \\
IMM & 64 & 4.222188 & 1.505536 & 0.84 & 6.73 \\
GOLD & 64 & 1381.59 & 227.2797 & 1068.3 & 1968.63 \\
INF & 64 & 3.160469 & 0.8872312 & 1.32 & 6.25 \\
GDP & 64 & 3.621559 & 3.20823 & -5.32 & 5.27 \\
FED & 64 & 1.207031 & 0.80617 & 0.25 & 2.5 \\
EXC & 64 & 13926 & 605.2054 & 13042 & 16310 \\
\hline
\end{tabular}

Table 6. Descriptive Statistics of Conventional Banking Model

\begin{tabular}{lccccc}
\hline \multicolumn{1}{c}{ Variable } & Obs & Mean & Std. Dev & Min & Max \\
\hline NIM & 64 & 5.095403 & 0.380995 & 4.311298 & 5.650547 \\
CAR & 64 & 22.89055 & 0.6955486 & 21.04509 & 24.50239 \\
LDR & 64 & 90.69831 & 3.208027 & 82.32749 & 96.18617 \\
LA & 64 & 17.00381 & 1.35003 & 14,63836 & 19.80454 \\
MM & 64 & 4972344 & 0.9420423 & 3.12 & 7.96 \\
GOLD & 64 & 1381.59 & 227.2797 & 1068.3 & 1968.63 \\
INF & 64 & 3.160469 & 0.8872312 & 1.32 & 6.25 \\
EXC & 64 & 13926 & 605.2054 & 13042 & 16310 \\
\hline
\end{tabular}

\subsubsection{Analysis of Correlation}

Statistics for correlations between variables are illustrated in Table 7. Correlation analyses between dependent and independent variables were carried out to identify the strength of the direction of the relationship between dependent and independent variables. 
Table 7. Correlations between variables - Islamic banking model

\begin{tabular}{|c|c|c|c|c|c|c|c|c|c|c|c|}
\hline $\mathrm{Obs}=64$ & iZscore & iCAR & NPF & FDR & PL & IMM & GOLD & INF & GDP & FED & EXC \\
\hline iZscore & 1.0000 & & & & & & & & & & \\
\hline iCAR & 0.8423 & 1.0000 & & & & & & & & & \\
\hline NPF & -0.8596 & -0.8942 & 1.0000 & & & & & & & & \\
\hline FDR & -0.7206 & -0.8458 & 0.7371 & 1.0000 & & & & & & & \\
\hline PL & -0.2690 & 0.0428 & 0.2226 & -0.1648 & 1.0000 & & & & & & \\
\hline IMM & -0.3429 & -0.3008 & 0.3050 & 0.3332 & 0.1584 & 1.0000 & & & & & \\
\hline GOLD & 0.5275 & 0.6054 & -0.6449 & -0.5350 & -0.2400 & -0.6723 & 1.0000 & & & & \\
\hline INF & -0.4686 & -0.6643 & 0.6459 & 0.5978 & -0.0352 & 0.3992 & -0.8010 & 1.0000 & & & \\
\hline GDP & -0.3367 & -0.4707 & 0.5080 & 0.3431 & 0.2145 & 0.5125 & -0.8687 & 0.7355 & 1.0000 & & \\
\hline FED & 0.4178 & 0.4140 & -0.3235 & -0.4650 & 0.1886 & 0.3344 & -0.3207 & 0.0905 & 0.5132 & 1.0000 & \\
\hline EXC & 0.6395 & 0.7520 & 0.6779 & -0.5357 & -0.0274 & -0.1873 & 0.4560 & -0.4933 & -0.4337 & 0.1797 & 1.0000 \\
\hline
\end{tabular}

Table 8. Correlations between variables - the conventional banking model

\begin{tabular}{|c|c|c|c|c|c|c|c|c|c|}
\hline Obs $=64$ & Z-score & NIM & CAR & LDR & LA & MM & GOLD & INF & EXC \\
\hline Z-score & 1.0000 & & & & & & & & \\
\hline NIM & 0.4939 & 1.0000 & & & & & & & \\
\hline CAR & -0.2345 & -0.3030 & 1.0000 & & & & & & \\
\hline LDR & 0.7465 & 0.1776 & -0.3003 & 1.0000 & & & & & \\
\hline LA & -0.5909 & -0.0181 & 0.1750 & -0.8718 & 1.0000 & & & & \\
\hline MM & 0.5326 & 0.4027 & -0.4712 & 0.7405 & -0.6864 & 1.0000 & & & \\
\hline GOLD & -0.7070 & -0.8325 & 0.4380 & -0.5061 & 0.3247 & -0.6845 & 1.0000 & & \\
\hline INF & 0.5687 & 0.7222 & -0.5211 & 0.2898 & -0.1533 & 0.4702 & -0.8010 & 1.0000 & \\
\hline EXC & -0.1798 & -0.7518 & -0.0241 & 0.1673 & -0.2840 & -0.0410 & 0.4560 & -0.4933 & 1.0000 \\
\hline
\end{tabular}


From the data presented in Table 7, variables of iCAR and NPF of Islamic banking had multicollinearity, known from a correlation score of more than 0.8000 . To anticipate spurious regression in the Islamic banking model, we dropped the iCAR variable. Then, we used NPF, FDR, PL, and IMM as independent variables of the Islamic banking stability model and INF, GDP, FED, and EXC as control variables to anticipate unobserved heterogeneity.

From the data presented in Table 8, the correlation score was lower than 0.8000 , and it can be seen in general that there was no multicollinearity among conventional banking variables. It can be assumed that the regression model of Islamic and conventional stability models was considered good to predict correlations among variables.

Table 9. Variable Coefficient of Islamic Banking Model

\begin{tabular}{lrcc}
\hline \multicolumn{1}{c}{ Variable } & Coefficient & t-value & Significance \\
\hline iZscore & -2.432778 & -3.82 & Significant \\
NOM & 1.930962 & 39.39 & Significant \\
NPF & -0.017677 & -0.60 & Not Significant \\
LIQ & -0.001838 & -0.34 & Not Significant \\
FDR & -0.012866 & -1.96 & Significant \\
LPS Potential & -0.134906 & -4.71 & Significant \\
IMM & -0.036985 & -2.13 & Significant \\
INF & 0.000294 & 0.01 & Not Significant \\
GDP & -0.011791 & -0.96 & Not Significant \\
FED & -0.046418 & -0.89 & Not Significant \\
EXC & 0.000134 & -3.30 & Significant \\
\hline
\end{tabular}

Table 10. Variable Coefficient of Conventional Banking Model

\begin{tabular}{lrcc}
\hline \multicolumn{1}{c}{ Variable } & Coefficient & t-value & Significance \\
\hline Z-score & -21.86102 & -3.35 & Significant \\
CAR & 0.151206 & 1.49 & Not Significant \\
NPL & -210.5472 & -4.75 & Significant \\
NIM & 1.124699 & 4.63 & Significant \\
LDR & 0.095508 & 2.71 & Significant \\
LA & -0.042645 & -0.66 & Not Significant \\
MM & 0.005687 & 0.05 & Not Significant \\
INF & 0.085509 & 0.89 & Not Significant \\
GDP & 0.041595 & 1.02 & Not Significant \\
FED & -0.161970 & -1.49 & Not Significant \\
EXC & 0.000504 & 3.10 & Significant \\
\hline
\end{tabular}

Next, we performed a Z-score regression of the Islamic banking model with independent and control variables. The Islamic banking stability index (iZscore) was significantly influenced by the level of Net Operating Margin, financing to deposit ratio, Potential Loss Profit Sharing, Islamic Money Market Rate, and Exchange Rate. However, non-performing financing did not affect 
stability because the profit-sharing system implemented by Islamic banking stability was more influenced by potential loss and profit-sharing ratio.

Meanwhile, the conventional banking stability index was significantly influenced by the level of Non Performing Loans, Net Interest Margin, Loan to Deposit Ratio, and Exchange Rates.

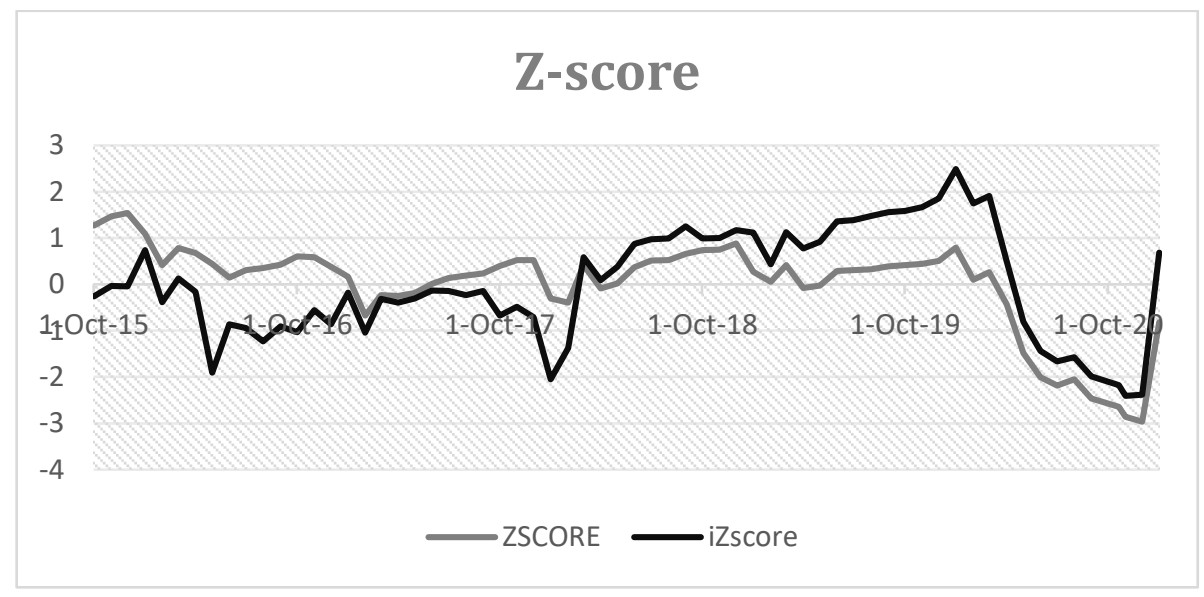

Figure 4. Banking Stability by Z-score

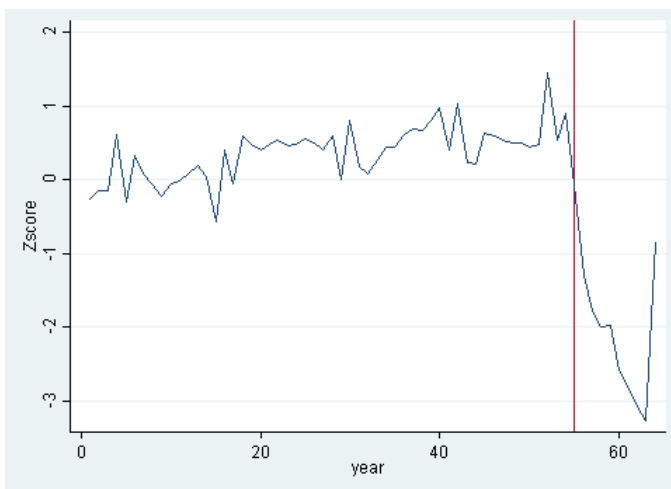

(a) Conventional

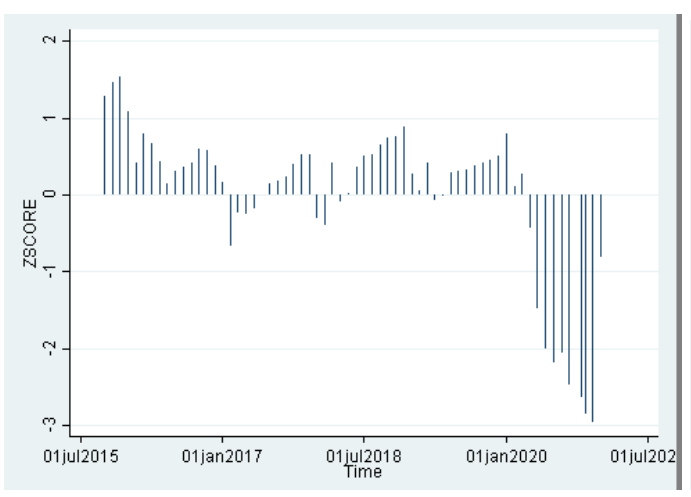

(a) Conventional

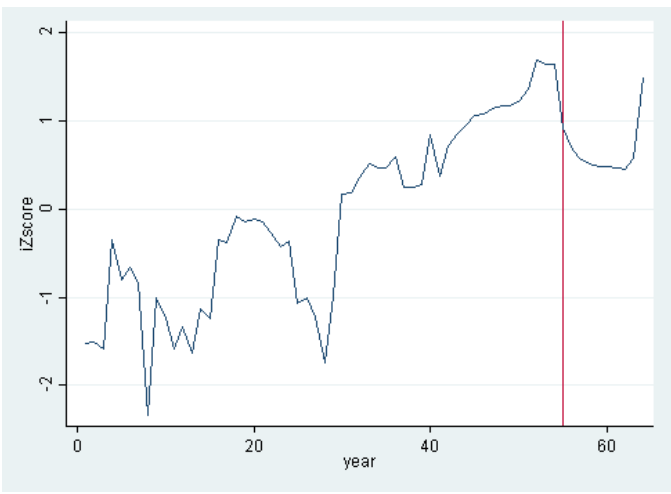

(b) Islamic

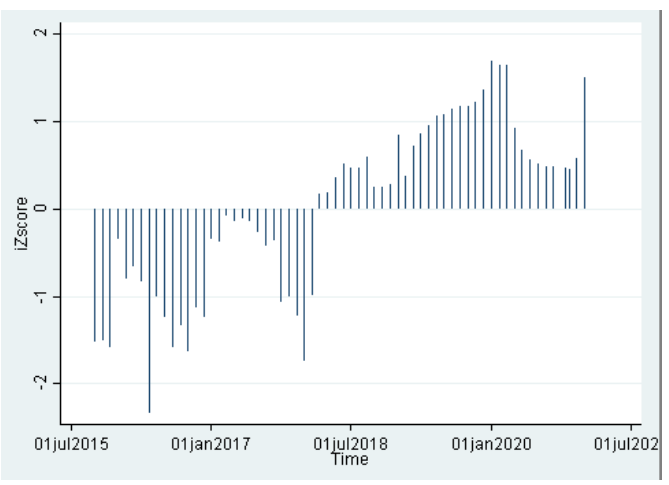

(b) Islamic

Figure 5. Z-score Fluctuation and Structural Break 
Both conventional and Islamic banking stability indexes by Z-score experienced a structural break in April 2020, while the pandemic COVID-19 struck all over Indonesia and influenced the Indonesian financial sector. These findings align with the IMF research paper (IMF, 2020).

Table 11. Conventional Bank Stability

\begin{tabular}{lccc}
\hline Conventional bank & Freq. & Percent & cum \\
\hline Stable, Z-score $>0.0$ & 45 & 70.31 & 29.69 \\
\hline Unstable, Z-score $<0.0$ & 19 & 29.69 & 100.00 \\
\hline Total & 64 & 100.00 & \\
\hline \multicolumn{4}{c}{ Table } \\
\multicolumn{4}{c}{ 12. Islamic Bank Stability } \\
\hline Islamic bank & Freq. & Percent & cum \\
\hline Stable, Z-score $>0.0$ & 35 & 54.69 & 45.31 \\
\hline Unstable, Z-score $<0.0$ & 29 & 45.31 & 100.00 \\
\hline Total & 64 & 100.00 & \\
\hline
\end{tabular}

Next, we analyzed the conventional and Islamic banking stability indexes. Based on the structural break of Indonesia's banking industry through a pandemic, the switching process of banking stability fluctuation occurred in April 2020. Thus, we divided regime 1 as stable and regime 2 as unstable conditions. Conventional banking stability index had 45 times in stable condition and 19 times in unstable condition. Meanwhile, the Islamic banking stability index had 35 times stable and 29 times unstable. The conventional and Islamic banking stability index fluctuation is depicted in Figure 4.

\subsubsection{Stationery Test}

Table 13. Stationery Test - Augmented Dickey-Fuller Test

\begin{tabular}{ccc}
\hline Dickey-Fuller Test & Level $\mathbf{z}(\mathrm{t})$ & 1st Difference \\
\hline Z-score & 0.3731 & 0.0000 \\
iZsore & 0.3644 & 0.0000 \\
CAR & 0.1351 & 0.0000 \\
NIM & 0.3799 & 0.0000 \\
LDR & 0.6616 & 0.0543 \\
MM & 0.3900 & 0.2417 \\
NOM & 0.2564 & 0.0000 \\
NPF & 0.5996 & 0.0074 \\
LIQ & 0.4697 & 0.0000 \\
FDR & 0.2888 & 0.0000 \\
PLS & 0.1041 & 0.0000 \\
IMM & 0.0080 & 0.0000 \\
INF & 0.0156 & 0.0000 \\
GDP & 0.8062 & 0.0000 \\
FED & 0.7189 & 0.0000 \\
EXC & 0.0727 & 0.0000 \\
\hline
\end{tabular}


After that, we conducted the stationery test using the Augmented DickeyFuller Test for all variables. If a time series is stationary, the data variance is not affected by changes in time, so it is in statistical equilibrium (Gujarati, 2003). From the stationery test, all variables except Money Market Rate were stationary at first differencing.

\subsubsection{Optimum Lag}

Tabel 14. Optimum Lag Conventional

\begin{tabular}{ccccccc}
\hline Lag & LogL & LR & FPE & AIC & SC & HQ \\
\hline 0 & -652.6221 & NA & 0.021315 & 21.69253 & $22.00397^{*}$ & $21.81459^{*}$ \\
1 & -546.3125 & $177.7636^{*}$ & $0.009549^{*}$ & $20.86271^{*}$ & 23.97711 & 22.08327 \\
2 & -488.2526 & 79.95140 & 0.023911 & 21.61484 & 27.53221 & 23.93391 \\
\hline
\end{tabular}

* indicates lag order selected by the criterion

Tabel 15. Optimum Lag Islamic Banking

\begin{tabular}{ccccccc}
\hline Lag & LogL & LR & FPE & AlC & SC & HQ \\
\hline 0 & -711.0579 & NA & 0.000530 & 23.67403 & $24.05468^{*}$ & $23.82321^{*}$ \\
1 & -586.8409 & $199.5617^{*}$ & $0.000505^{*}$ & $23.56856^{*}$ & 28.13635 & 25.35872 \\
2 & -480.5841 & 132.3856 & 0.001189 & 24.05194 & 32.80687 & 27.48308 \\
\hline
\end{tabular}

* indicates lag order selected by the criterion

The optimum lag test results found that if the smallest AIC is at Lag 1, it means that the Z-score is influenced by the volatility of independent variables in one month before. The Islamic and conventional banking stability index are influenced by the observed independent variables ranging from one month.

Form stability test, it is concluded that conventional dan Islamic banking stability models were stable in lag 1.

The probability of regime 1 (stable condition) for Z-score Islamic banking was 0.9832801 , and regime 2 (unstable condition) was 0.0152959. It was very persistent, and it was not easy to go back to the previous state. It means that the probability of Islamic banking in stable condition (regime 1) was $98.32 \%$, bigger than the probability of unstable condition (regime 2), equal $1.53 \%$. Meanwhile, the probability regime 1 (stable condition) of conventional banking Z-score was 0.9550105 and regime 2 (stable condition) of conventional banking Z-score was 0.013941 . It indicates that the probability of conventional banking in stable condition (state 1 ) was $95.50 \%$, while the probability of unstable condition (state 2 ) was $1.39 \%$. This study resulted in the iZscore of Islamic banking higher than conventional banking Z-score. Meanwhile, conventional banking's stable condition was $22.5 \%$ longer than Islamic banks. 
Tabel 16. Stability Test Conventional

\begin{tabular}{cc}
\hline Root & Modulus \\
\hline$-0.381866-0.301580 i$ & 0.486592 \\
$-0.381866+0.301580 i$ & 0.486592 \\
$0.391863-0.108585 i$ & 0.406629 \\
$0.391863+0.108585 i$ & 0.406629 \\
$0.071011-0.348622 i$ & 0.355781 \\
$0.071011+0.348622 i$ & 0.355781 \\
-0.292764 & 0.292764 \\
$-0.049810-0.134631 i$ & 0.143550 \\
$-0.049810+0.134631 i$ & 0.143550 \\
\hline
\end{tabular}

No root lies outside the unit circle.

VAR satisfies the stability condition.

Tabel 17. Stability Test Islamic Banking

\begin{tabular}{cc}
\hline Root & Modulus \\
\hline$-0.394496-0.222001 i$ & 0.452671 \\
$-0.394496+0.222001 i$ & 0.452671 \\
$0.290742-0.261753 i$ & 0.391210 \\
$0.290742+0.261753 i$ & 0.391210 \\
$-0.143258-0.294509 i$ & 0.327503 \\
$-0.143258+0.294509 i$ & 0.327503 \\
$-0.294813-0.098056 i$ & 0.310692 \\
$-0.294813+0.098056 i$ & 0.310692 \\
$0.093868-0.195347 i$ & 0.216730 \\
$0.093868+0.195347 i$ & 0.216730 \\
.011891 & 0.011891 \\
\hline
\end{tabular}

No root lies outside the unit circle.

VAR satisfies the stability condition.

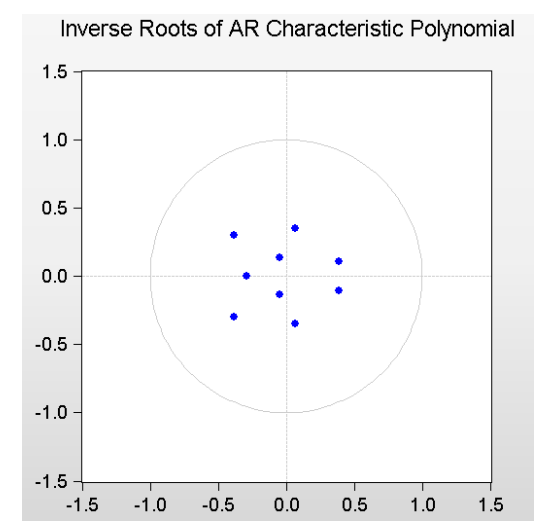

Conventional Banking

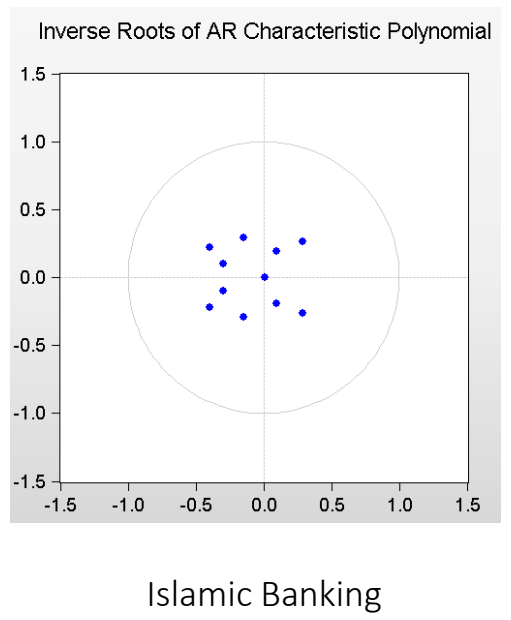

Islamic Banking

Figure 6. VAR Stability Condition 
Table 18. Probability and Duration Transition of Z-score

\begin{tabular}{lcccc}
\hline \multirow{2}{*}{$\begin{array}{c}\text { Structural } \\
\text { Break }\end{array}$} & \multicolumn{2}{c}{ Islamic Z-score } & \multicolumn{2}{c}{ Conventional Z-score } \\
\cline { 2 - 5 } & Probability & Duration & Probability & Duration \\
\hline Regime 1: Stable & 0.9832801 & 35 & 0.9550105 & 45 \\
\hline Regime 2: Unstable & 0.0152959 & 29 & 0.013941 & 19 \\
\hline
\end{tabular}

Source: Stata analytical tools

\section{Conclusion and Recommendation}

\subsection{Conclusion}

This study measured the level of stability of the dual banking system in Indonesia from January 2015 to February 2021 using the Z-score measurement model. Based on calculations from banking data, it showed that the level of stability of Islamic and conventional banking in Indonesia was different. By calculating the Z-score, the Islamic banking system had a higher level of stability than the conventional banking system. Based on the results of Markov switching through the estimation of the probability and duration of switching in stable conditions, in general, Islamic banking is considered more stable than conventional banking (Hasan, 1995).

The probability of regime 1 (stable condition) for z-score Islamic banking was 0.9832801 , and regime 2 (unstable condition) was 0.0152959; it was very persistent, and it was not easy to go back to the previous state. Meanwhile, the probability regime 1 (stable condition) of conventional banking Z-score was 0.9550105, and regime 2 (stable condition) of conventional banking Zscore was 0.013941 . This study resulted in an iZscore of Islamic banking higher than conventional banking Z-score, while conventional banking's stable condition was $22.5 \%$ longer than Islamic banks.

Based on the model 1 regression result, the conventional banking stability index was significantly influenced by the level of Non-Performing Loans, Net Interest Margin, Loan to Deposit Ratio, and Exchange Rates. Meanwhile, from model 2, the Islamic banking stability index (iZscore) was significantly influenced by the level of Net Operating Margin, Financing to deposit ratio, Potential Loss Profit Sharing, Islamic Money Market Rate, and Exchange Rate. However, non-performing financing did not affect Islamic banking stability because the profit-sharing system implemented by Islamic banking stability was more influenced by the ratio of potential loss and profit-sharing system. 


\subsection{Recommendation}

\subsubsection{For Practitioners}

Since Islamic banking and conventional banking models are different, we recommend for Islamic banking practitioners to maintain the potential profit and loss sharing ratio, while the conventional banking practitioners should maintain the non-performing loan or bad debt ratio in shock condition.

\subsubsection{For Regulators}

From data analysis and conclusion, our recommendations for regulators are to maintain the banking system's stability through the pandemic condition, maintain non-performing loans of bad debts, and tighten liquidity in shock conditions. Regulators should consider the differentiation between Islamic and conventional banking models. From our analysis, the stability index of the Islamic banking model (iZscore) was influenced by the potential of profit and loss sharing, while the conventional banking stability index was influenced by non-performing loans (bad debt ratio).

This research discusses the stability of the banking system and improving strategies in dealing with uncertain financial conditions. Since the stability of Islamic banking is better than conventional banking, we recommend that the government support the increase of the market share of Islamic banking to stabilize Indonesia's banking industry.

\subsubsection{For Further Research}

We also provide recommendations to further researchers to research for a longer period to obtain maximum dual banking system stability results. 


\section{References}

Abedifar, P., Molyneuxtc, P., \& Tarazi, A. (2012). Risk in Islamic banking. Review of Finance, 17(6), 2035-2096, doi: https://doi.org/10.1093/rof/rfs041

Albuquerque, P., \& Rajhi, W. (2019). Banking stability, natural disasters, and state fragility: Panel VAR evidence from developing countries. Research in International Business and Finance. (50), 430-443.

Alqahtani, F., \& Mayes, D. G. (2018). Financial stability of Islamic banking and the global financial crisis: Evidence from the Gulf Cooperation Council. Economic Systems, 42(2), 346-360.

Bai, J. , Peron, P. (2003). Critical values for multiple structural change tests. Econometrics Journal 1, 1-7.

Barattieri, A., Eden, M., Stevanovic, D. (2020). Risk sharing, efficiency of capital allocation, and the connection between banks and the real economy. Journal of Corporate Finance.

Cihak, M., \& Hesse, H. (2008). Islamic banks and financial stability: An empirical analysis, IMF Working Paper WP/08/16.

Cihak, M., \& Hesse, H. (2010). Islamic banks and financial stability: An empirical analysis. Journal of Financial Services Research, 38(2), 95-113.

Chow, G.C. (1960). Tesis of equality between sets of coefficients in two linier regressions. Econometrica, Vol. 28, 591-605.

Donthu, N., \& Gustafsson, A. (2020). Effects of covid-19 on business and research. Journal of Business and Research, 117, 284-289.

Elnahass, M., Trinh, V. Q., \& Li, T. (2021). Journal of International Financial Markets, Institutions \& Money Global banking stability in the shadow of Covid-19 outbreak. Journal of International Financial Markets, Institutions \& Money, 72, 101322. https://doi.org/10.1016/j.intfin.2021.101322

Gadanecsz, B., Kaushik, J. (2008). Measures of Financial Stability - A Review. Irving Fisher Committee Bulletin, no. 31, pp. 365-383.

Ghosh, S. (2011). A simple index of banking fragility: Application to Indian data: Reserve Bank of India, Mumbai, India. The Journal of Risk Finance. 12(2), 112-120.

Gorton, G., \& Winton, A. (2003). Financial intermediation. In GM Constantinides, M. Harris, \& RM Stulz (Eds.), Handbook of the Economics of Finance (Vol.1, Issue SUPPL. PART A, pp. 431-552). Elsevier Masson SAS. https://doi.org/10.1016/S1574-0102(03)01012-4.

Gujarati, D. N. (2003). Basic Econometric (4th ed). New York: McGraw-Hill.

Hamilton, J.D. (1989). A New Approach to the Economic Analysis of Nonstationary Time Series and the Business Cycle. Econometrica, Vol. 57, 
No. 2, 357-384.

Hasan, Z. (1995). Economic Development in Islamic Perspective: Concept, Objectives, and Some Issues. Journal of Islamic Economics, 1(6), 80-111.

International Monetary Fund (IMF). (2015). IMF elibrary data. Washington, DC: International Monetary Fund.

International Monetary Fund (IMF). (2020). World economic outlook, April 2020: The Great Lockdown. Retrived from: www.imf.org/en/Publications/WEO/Issues/2020/04/14/weo-april2020. [Accessed 14 April. 2020].

Kabir, M. N., Worthington, A. \& Gupta, R. (2015). Comparative credit risk in Islamic and Conventional Bank. Pacific-Basin Finance Journal, Elsevier, Vol. 34,327-353.

Kočišová. (2011). Banking Stability Index: A Cross-Country Study. ResearchGate, 197-208.

Krolzig, H. (1997). Markov-switching vector autoregressions modeling, statistical inference, and application to business cycle analysis (PDW (Institut fur MW Fandel, Prof. Dr. G. (Fachbereich Wirtschaftwissenschaften); Trockel (ed.)). Berlin Heidelberg: SpringerVerlag

Krolzig, H. M. (2000). Predicting markov - switching vector autoregressions., Working paper. Oxford: Department of Economics and Nuffield College Oxford.

Lee, C. C., \& Lee, C. 2019. Oil Price Shocks and Chinese Banking Performance: Do Country Risks Matter?. Energy Economic, Vol. 77, 46-53.

Martin, Č., \& Hesse, H. (2010). Islamic Banks and Financial Stability: An Empirical Analysis. 95-113. https://doi.org/10.1007/s10693-010-0089-0

Nurfalah, I., \& Rusydiana, A. S. (2021). The regime switching of cycle instability of Islamic banking and the economy: Evidence from Indonesia, Malaysia and Pakistan. Journal of Islamic Monetary Economics and Finance, 7 (2), 233-262.

Nurfalah, I., Rusydiana, A. S, Laila, N., \& Cahyono, E. F. (2018). Early warning to banking crises in the dual financial system in Indonesia: The Markov switching approach. Journal of King Abdul Aziz University, 31(2), 133-156. https://doi.org/10.4197/Islec

Ozili, P. K. (2018). Banking stability determinants in Africa. International Journal of Managerial Finance, 14(4), 462-483.

Rajhi, W., \& Hassairi, S. A. (2013). Islamic banks and financial stability: A comparative empirical analysis between MENA and Southeast Asian Countries. SSRN Electronic Journal, 37, doi: 10.2139/ssrn.2010126. 
Yunita $\mid$ Stability Measurement of Indonesia Dual Banking System in The Shadow of Covid 19 Outbreak

Reinhart, C. M, \& Rogoff, K. S. (2013). Financial and sovereign debt crises: Some lessons learned and those forgotten. IMF Working Paper, 13(266).

Risfandy, T., Tarazi, A., \& Trinugorho, I. (2020). Competition in dual market: Implications for banking system stability. Global Finance Journal.

Ryu, D., \& Yu, J. (2021). Nonlinear Effectof Subordinated Debt Changes on Bank Performanc. Finance Research Letters.

Sanchez, C., Garcia, V. Marques, A. I., \& Sanchez, J. S. (2016). Financial distress prediction using the hybrid associative memory with translation. Applied Soft Computing Journal. 44. 144-152.

Sharma, P., Leung, T. Y., Kingshott, R. P., Davcik, N. S., \& Cardinali, S. (2020). Managing uncertainty during a global pandemic: An international business perspective. Journal of Business and Research. 116, 188-192.

Schaeck, K., \& Cihak, M. (2014). Competition, efficiency, and stability in banking. Financial Management 43(1), 215-241.

Tong, H., \& Lim, K. S. (1980). Threshold autoregression, limit cycles and cyclical data. Journal of the Royal Statistical Society. Series B (Methodologica), Vol. 42, No. 3, 245-292.

Untoro., R. Priyo. \& A. Widodo. (2014). The review of the use of payment instruments as macroeconomic leading indicators. Wp/6/2014 Working Paper of Bank Indonesia.

Van Dijk, D., Terasvirta, T., \& Franses, P.H. (2002). Smooth transition autoregressive models: A survey of recent developments. Econometric Reviews, Taylor \& Francis Journals, Vol. 21(1), 1-47.

Zahra, S. F., Ascarya \& Huda, N. (2018). Stability measurement of dual banking system in Indonesia : markov switching approach. 10(1), 25-52. 